\title{
Perceived risk factors and risk pathways of Rift Valley fever in cattle in ljara district, Kenya
}

\author{
Authors: \\ Nelson O. Owange ${ }^{1}$ \\ William O. Ogara ${ }^{1}$ \\ Jacqueline Kasiiti \\ Peter B. Gathura ${ }^{1}$ \\ Sam Okuthe ${ }^{3}$ \\ Rosemary Sang ${ }^{4}$ \\ Hippolyte Affognon ${ }^{4}$ \\ Washington Onyango-Ouma \\ Tobias T.O. Landmann ${ }^{4}$ \\ Murithi Mbabu² \\ Affiliations: \\ ${ }^{1}$ Department of Public \\ Health Pharmacology and \\ Toxicology, University of \\ Nairobi, Kenya \\ ${ }^{2}$ Department of Livestock, \\ Ministry of Agriculture, \\ Livestock and Fisheries, \\ Kenya \\ ${ }^{3}$ Emergency Centre for \\ Transboundary Animal \\ Diseases, Food and \\ Agriculture Organization of \\ the United Nations, Kenya \\ ${ }^{4}$ International Centre for \\ Insect Physiology and \\ Ecology, Nairobi, Kenya \\ ${ }^{5}$ College of Humanities and \\ Social Sciences, University of \\ Nairobi, Kenya

\section{Correspondence to:} \\ Nelson Owange \\ Email: \\ owanelson@yahoo.com \\ Postal address: \\ PO Box 36001, Nairobi \\ 00200, Kenya \\ Dates: \\ Received: 27 Feb. 2014 \\ Accepted: 21 Aug. 2014 \\ Published: 20 Nov. 2014 \\ Read online:

Ijara district in Kenya was one of the hotspots of Rift Valley fever (RVF) during the 2006/2007 outbreak, which led to human and animal deaths causing major economic losses. The main constraint for the control and prevention of RVF is inadequate knowledge of the risk factors for its occurrence and maintenance. This study was aimed at understanding the perceived risk factors and risk pathways of RVF in cattle in Ijara to enable the development of improved community-based disease surveillance, prediction, control and prevention. A cross-sectional study was carried out from September 2012 to June 2013. Thirty-one key informant interviews were conducted with relevant stakeholders to determine the local pastoralists' understanding of risk factors and risk pathways of RVF in cattle in Ijara district. All the key informants perceived the presence of high numbers of mosquitoes and large numbers of cattle to be the most important risk factors contributing to the occurrence of RVF in cattle in Ijara. Key informants classified high rainfall as the most important (12/31) to an important (19/31) risk factor. The main risk pathways were infected mosquitoes that bite cattle whilst grazing and at watering points as well as close contact between domestic animals and wildlife. The likelihood of contamination of the environment as a result of poor handling of carcasses and aborted foetuses during RVF outbreaks was not considered an important pathway. There is therefore a need to conduct regular participatory community awareness sessions on handling of animal carcasses in terms of preparedness, prevention and control of any possible RVF epizootics. Additionally, monitoring of environmental conditions to detect enhanced rainfall and flooding should be prioritised for preparedness.

\section{Introduction}

Rift Valley fever (RVF) is a viral disease caused by Rift Valley fever virus (RVFV), a member of the genus Phlebovirus, family Bunyaviridae. It is a mosquito-borne viral zoonosis that periodically causes disease outbreaks in humans and livestock (Davies, Linthicum \& James 1985). The virus is transmitted to humans through direct contact with tissues and blood of infected animals as well as bites from infected mosquitoes. The disease has been endemic in sub-Saharan Africa since 1912 (Peters \& Linthicum 1994). Periodic outbreaks have been reported in many African countries, Saudi Arabia and Yemen (Al-Afaleg et al. 2003; Centers for Disease Control and Prevention [CDC] 2007; Gerdes 2004; Woods \& Karpati 2002).

Outbreaks of RVF in Ijara district have been associated with unusually heavy rainfall that causes extensive flooding of basins and low-lying grassland depressions called dambos, triggering mass emergence of Aedes mosquitoes (Anyangu et al. 2010). In 1997/1998 and 2006/2007, massive outbreaks of RVF occurred in East Africa, both associated with El Niño events (CDC 2007; Woods \& Karpati 2002), with an estimated 27500 human cases and more than 600 deaths reported in 1997/1998 in Kenya alone. Historical outbreaks of RVF 'since the early 1950s have been associated with cyclical patterns of the El Niño/Southern Oscillation (ENSO) phenomenon, which results in elevated and widespread rainfall over the RVF-endemic areas of Africa' (Anyamba et al. 2010:43). The two outbreaks (in 1997/1998 and 2006/2007) were the most notable in terms of public health and socio-economic impact (Murithi et al. 2010).

Rift Valley fever virus has distinct endemic and epidemic cycles. During the endemic cycle, the virus persists in inter-epidemic periods through vertical transmission in Aedes mosquito eggs (Davies et al. 1985). Flooding of mosquito habitats can introduce RVFV into domestic animal populations by the emergence of vertically infected Aedes mosquitoes. Epidemic cycles are driven by the subsequent expansion of various Culex mosquito populations, which serve as excellent secondary vectors if immature mosquito habitats remain flooded long enough (Anyamba et al.

How to cite this article: Owange, N.O., Ogara, W.O., Kasiiti, J., Gathura, P.B., Okuthe, S., Sang, R. et al., 2014, 'Perceived risk factors and risk pathways of Rift Valley fever in cattle in ljara district, Kenya', Onderstepoort Journal of Veterinary Research 81(1), Art. \#780, 7 pages. http://dx.doi.org/10.4102/ojvr.v81i1.780

Copyright: $\subset$ 2014 . The Authors. Licensee: AOSIS OpenJournals. This work is licensed under the Creative Commons Attribution License. 
2010). Apart from the mosquito transmission to domestic animals and humans during the epidemic cycle, aerosols and contact between infected animals and humans can transmit the virus to humans (Anyamba et al. 2010). The virus is amplified in people and animals. Flat topography, presence of water-retaining soil types and dense bush cover are important factors for flooding and/or mosquitoes breeding (Anyangu et al. 2010).

Risk pathway analysis involves investigation of the possibility of entry, release, exposure and eventual consequences of the disease. It helps establish the routes the disease follows for possible entry, establishment and spread (Breiman et al. 2010). Factors such as vectors, hosts, animal movement patterns and the role of wildlife are used to estimate the probability of occurrence of the disease. In the USA, risk pathway analysis for emerging and re-emerging diseases has been adopted in order to establish exact areas to target for better control and prevention (Kasari et al. 2008). Breiman et al. (2010) documented that RVFV can enter a new area through infected mosquitoes and their eggs, infected livestock, infected wildlife, infected humans and smuggling (terrorist activity). The virus can then spread through mosquito bites, environmental contamination by infected carcasses or aborted foetuses and movement of infected animals and humans, leading to massive losses of lives, livelihoods and trade.

About $90 \%$ of the population of Ijara is directly dependent on livestock for food and as a source of income. During the last outbreak, a ban on livestock trade and imposition of quarantine resulted in severe economic losses of more than $\$ 9.3$ million (Murithi et al. 2010). In Ijara district, cattle are driven over long distances towards the Tana River Delta or into Boni forest, passing through various ecosystems.

Ijara district ${ }^{1}$ was one of the hotspots during the last RVF outbreaks in the arid and semi-arid North-Eastern province of Kenya (Nguku et al. 2010). The nomadic and semi-nomadic pastoralist communities maintain large livestock herds even in circumstances of limited pasture and water. Outbreaks of RVF have caused major disruptions to public health and the economic mainstay of this population. The movement of these viruses amongst animals and vectors with occasional involvement of human populations under the influence of environmental factors required further study.

The study used key informant interviews to investigate the perceived risk factors and risk pathways associated with RVF in cattle along the livestock movement corridors in Ijara. It was part of a bigger project whose overall objective was to bring about a better understanding of the environmental, biotic and socio-economic drivers of the emergence of RVF and other arboviruses and the viable control options in the

1.ljara district is amongst the four districts (Lujis, Lagdera, Fafi and liara) of Gariss County after the promulgation of the new constitution in Kenya in 2010. Ijara district was carved out of Garissa district (the region of current Garissa County was originally called Garissa district) even before the new constitution. Many publications still use Garissa district to mean Garissa County including ljara district. However, some publications differentiate between ljara and Garissa district. In this publication, Garissa district refers to the district bordering ljara district to the north (see Figure 1). arid and semi-arid North-Eastern province of Kenya, with a focus on Ijara district, a major hotspot of the disease. The information from this study can be used to create awareness as well as to formulate prevention and mitigation measures for RVF.

\section{Materials and methods Study area}

The study was carried out in the arid and semi-arid region of North-Eastern Kenya, with Ijara district at the centre of the study. Ijara district is bordered by Garissa and Fafi districts to the north, Somalia to the east, Lamu district to the south and Tana River district to the west (Figure 1). It lies at approximately $33^{\circ} \mathrm{E}, 6^{\circ} \mathrm{N}$ and $43^{\circ} \mathrm{E}, 5^{\circ} \mathrm{S}$ and is devoid of mountains. It is characterised by low, undulating plains at an altitude ranging between 0 m.a.s.l. and 90 m.a.s.l.

Figure 2 is a map of Kenya showing the areas where RVF outbreaks occurred and their relationship with the study area.

The study area (Figure 1) falls in ecological Zone V-IV with a total forest cover of $2484 \mathrm{~km}^{2}$. Boni forest, which is an indigenous open canopy forest that forms part of the northern Zanzibar-Inhamdare coastal Forest Mosaic, covers a major part of the study area. A section of the forest, the Boni National Reserve, is under the management of the Kenya Wildlife Service as a protected conservation area. The soil types are black cotton and alluvial types, temperatures range between $15^{\circ} \mathrm{C}$ and $38^{\circ} \mathrm{C}$, bimodal rainfall ranges between $700 \mathrm{~mm}$ and $1000 \mathrm{~mm}$ per annum, and average relative humidity is $68 \mathrm{~mm}$.

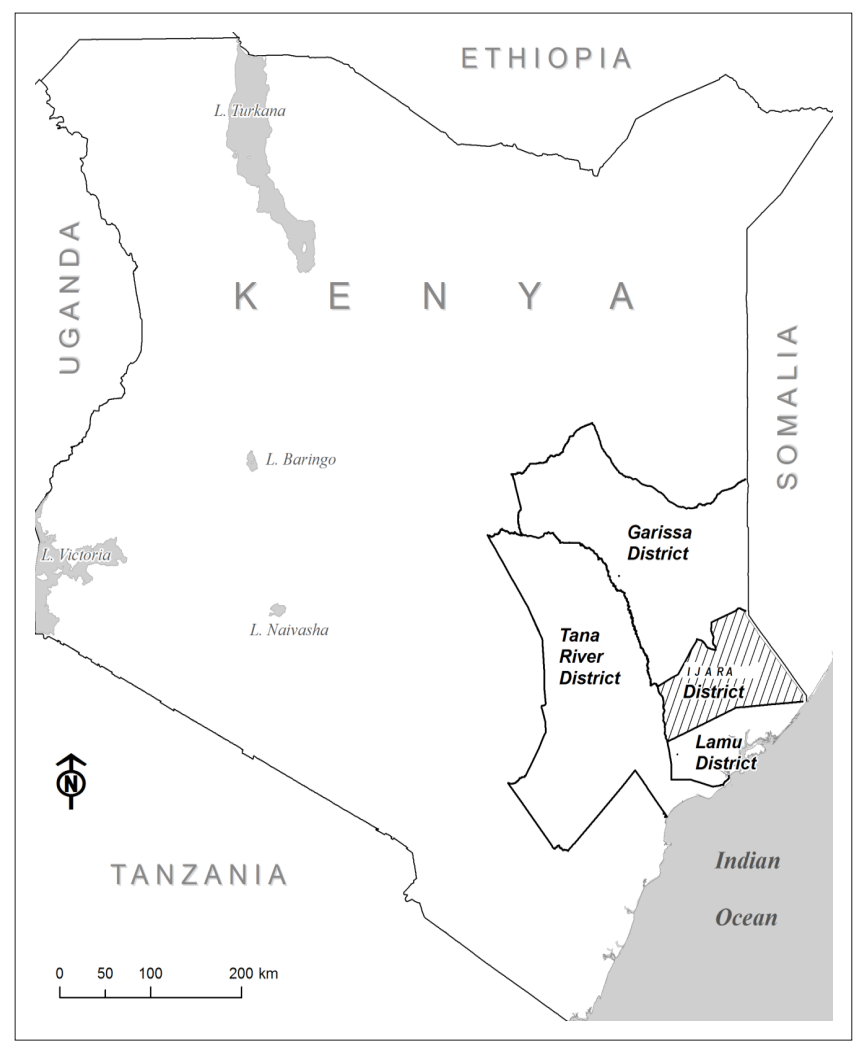

Source: International Centre for Insect physiology and Ecology (ICIPE) Earth Observation Unit FIGURE 1: Map of study area showing the relationship between the study area, the surrounding districts and Somalia. 


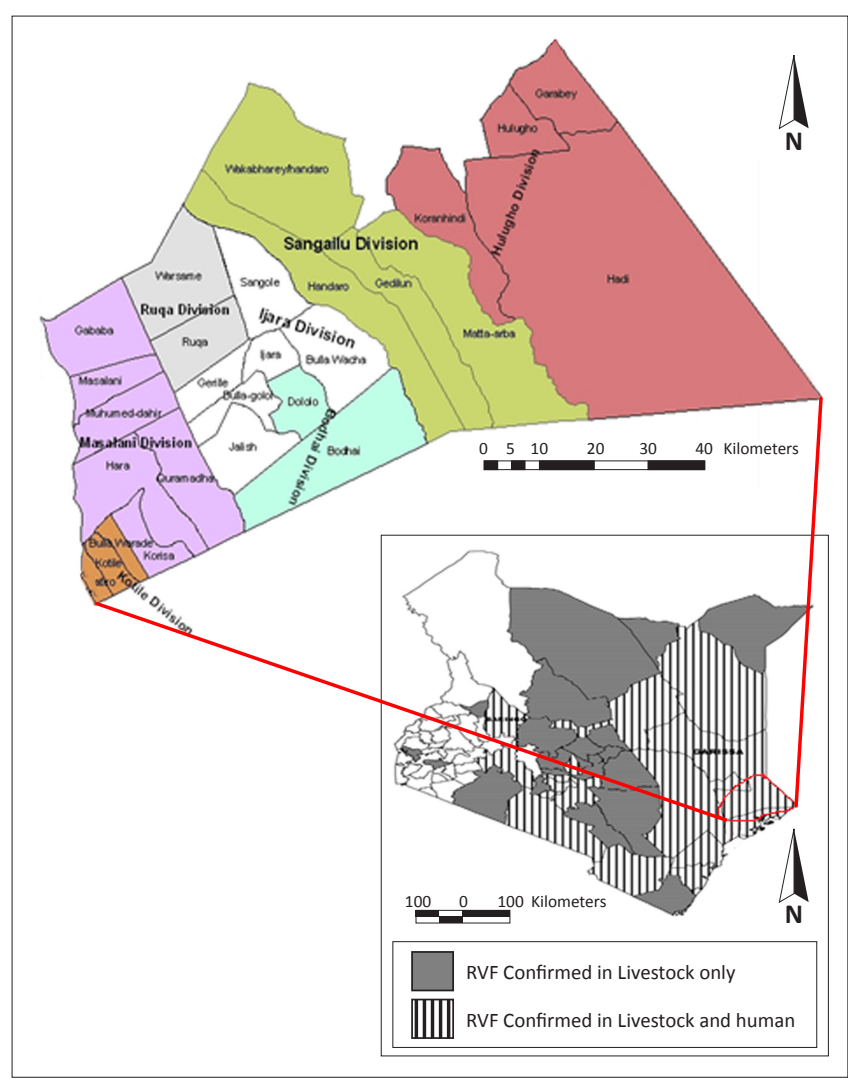

Source: Modified map from International Centre for Insect physiology and Ecology (ICIPE) Earth Observation Unit and Google

FIGURE 2: Map of Kenya showing Rift Valley fever endemicity and the relationship with the study area.

Migration in the district is occasioned by search for pasture during the dry seasons and involves movement of people and livestock to the Tana River Delta and the Boni forest area, where water and pasture are abundant long after the rainy season. Other movements in search of pasture and water are towards Fafi and Garissa districts and Somalia.

\section{Sampling method}

A cross-sectional study of the perceived risk factors and risk pathways of RVF for cattle in Ijara was carried out between August 2012 and June 2013. Purposive sampling was used to select 31 individuals who were later interviewed in order to describe the perceived risk factors and risk pathways for RVF in cattle as understood by the locals (Chambers 1981, 1994; World Bank 2004). Targeted stakeholders for 31 key informant interviews included local leaders, veterinary officers, animal health assistants, community-based animal health workers, Kenya Wildlife Service personnel and local administrative officers.

\section{Key informant interviews}

The key informant interviews were used to identify and rank the RVF-associated risk factors and risk pathways as perceived by the local pastoralists in the study area. It is important to note that some key informants were technical experts who may have given their opinion rather than the local communities' perception. The key informants listed the risk factors and used informal ranking, which was later cross-checked by a more formal pair-wise and matrix ranking and scoring. The identified pathways were also qualitatively ranked as high or high importance (4), medium or important (3), low or less important (2) or negligible or not important (1) or high (3), moderate (2) and low (1) in the study area by the respondents. These qualitative rankings had no set criteria and depended on the key informants' responses.

\section{Data analysis}

At the end of the data collection process, all information gathered was ranked and qualitative measures of perceived importance of risk factors and pathways summarised to address the objectives of the study.

\section{Results \\ Qualitative ranking of perceived Rift Valley fever risk factors}

According to the respondents, availability of vectors $(31 / 31=4)$, large number of cattle $(29 / 31=4 ; 2 / 31=3)$ and high rainfall $(12 / 31=4 ; 19 / 31=3)$ are rated most important and/or important risk factors associated with RVF in Ijara (Table 1). There was varied perception on soil types, dambos, bushy vegetation, wildlife and flat topography as risk factors, ranging from 3 (important) to 1 (not important). All the respondents rated drought as not important as a risk factor associated with RVF. High temperature was also rated as a less important to not important risk factor.

\section{Qualitative ranking of perceived Rift Valley fever entry pathways}

As shown in Table 2, the perceived entry risk pathways for RVF in Ijara district according to the key informants were infected mosquitoes, infected domestic animals, infected aborted foetuses and fluids and infected wild animals. All the respondents were in agreement that infected mosquitoes constituted the most likely entry pathway for RVF (31/31). Most of the respondents $(30 / 31)$ were in agreement that infected domestic animals could be classified as high means of RVF entry into Ijara district, whilst only one respondent classified it as medium means of RVF entry (1/31). The majority of the respondents $(30 / 31)$ perceived virus smuggling from neighbouring Somalia to be a negligible (unlikely) means of RVF virus entry.

\section{Qualitative ranking of perceived Rift Valley fever exposure or spread pathways}

The perceived exposure or spread risk pathway were bites from infected mosquitoes at livestock watering points, around cattle bomas, in bushy environments coming in contact with cattle as well as the exposure to contaminated pasture and environment by infected aborted foetuses and fluids. Most of the respondents perceived spread of RVFV through mosquitoes' bite to be one of the possible forms of spread, whilst environmental contamination by infected aborted foetuses and fluids was categorised as a medium to low-risk pathway (Table 3 and Figure 3). 


\section{Qualitative ranking of perceived Rift Valley fever outbreak consequences}

The most highly rated consequences are morbidity (30/31), quarantine $(31 / 31)$ and ban on trade (31/31). Ratings for abortion, mortality, loss of appetite, reduced production and vaccination consequences ranged between high, medium and low for each consequence (Table 4).

\section{Discussion}

The informants rated availability of vectors, large number of cattle and high rainfall highly as perceived risk factors associated with RVF in Ijara. These findings were supported by those of Anyangu et al. (2010), who showed a strong association between severe infections of RVF and handling of a large number of animals, closeness to water sources and mosquitoes in the 2006/2007 outbreak. Respondents' low rating on the role of wildlife in RVF transmission does not correspond with the findings of Evans et al. (2008), who detected RVF antibodies in warthogs, gerenuk, waterbuck and buffalo.

The risk pathway analysis was based on three possible stages: assessment (entry, exposure and consequence), communication and management. There were basically three pathways for consideration for the above analysis in relation to the possible entry of the RVF virus into the study area, transmission and spread of the virus and release of the virus to neighbouring areas.

TABLE 1: Summarised results for qualitative ranking of Rift Valley fever risk factors in cattle as perceived by the pastoralists' key informants in ljara, Kenya.

\begin{tabular}{|c|c|c|}
\hline Risk factor & Ranking: & $N \dagger$ \\
\hline \multirow[t]{2}{*}{ Rainfall } & 4 & 12 \\
\hline & 3 & 19 \\
\hline \multirow[t]{2}{*}{ Floods } & 4 & 27 \\
\hline & 3 & 4 \\
\hline \multirow[t]{4}{*}{ Dambos } & 4 & 2 \\
\hline & 3 & 9 \\
\hline & 2 & 18 \\
\hline & 1 & 2 \\
\hline \multirow[t]{3}{*}{ Soil types } & 3 & 4 \\
\hline & 2 & 25 \\
\hline & 1 & 2 \\
\hline \multirow[t]{2}{*}{ Bushy vegetation } & 3 & 15 \\
\hline & 2 & 16 \\
\hline \multirow[t]{4}{*}{ Wildlife } & 4 & 4 \\
\hline & 3 & 18 \\
\hline & 2 & 8 \\
\hline & 1 & 1 \\
\hline \multirow[t]{3}{*}{ Flat topography } & 3 & 1 \\
\hline & 2 & 24 \\
\hline & 1 & 6 \\
\hline \multirow[t]{2}{*}{ Large number of cattle } & 4 & 29 \\
\hline & 3 & 2 \\
\hline \multirow[t]{2}{*}{ High temperature } & 2 & 18 \\
\hline & 1 & 13 \\
\hline
\end{tabular}

Number of key informants was 31

$\dagger$, Numbers of key informants suggesting the $\$$, qualitative measure.

Score shows perceived degree of importance of Rift Valley fever risk factors: $4=$ most important, 3 = important, 2 = less important, 1 = not important.
The entry risk pathways for RVF in ljara district mentioned by the pastoralists were through infected mosquitoes, infected domestic animals, infected aborted foetuses and fluids and infected wild animals, which were corroborated by the study carried out by Breiman et al. (2010). The perceived exposure or spread risk pathways of infected mosquitoes at livestock watering points, around cattle bomas and in bushy environments coming into contact with cattle as well as the exposure to pasture and environment contaminated by infected aborted foetuses and fluids were indications of the communities' understanding of the risk factors associated with RVF. The likelihood of virus smuggling across the border with Somalia was rated as negligible. It is also important to note that the respondents considered aborted foetuses as a less important pathway in the entry and spread of RVF, a factor which does not correspond with the findings of Anyangu et al. (2010) that aborted foetuses were the single most important factors directly associated with severe RVF infections in humans during the 2006/2007 outbreak, compared to the presence of mosquitoes, water bodies and contact with livestock, which were jointly associated. Table 5 provides a summary of the risk pathway analysis.

\section{Conclusion}

Availability of the RVFV vectors (mosquitoes) and hosts (cattle) as well as high rainfall were the main risk factors understood by the locals to enable epidemics of RVF in Ijara.

The main perceived routes of entry, exposure and spread of RVF in Ijara were infected mosquitoes, infected domestic

TABLE 2: Summarised results for qualitative ranking of Rift Valley fever entry risk pathway in cattle as perceived by the pastoralists' key informants in ljara, Kenya.

\begin{tabular}{lll}
\hline Entry risk pathway & Ranking $\$$ & $N \dagger$ \\
\hline Infected domestic animals & 4 & 30 \\
& 3 & 1 \\
Infected aborted foetuses & 4 & 3 \\
and fluids & 3 & 17 \\
& 2 & 11 \\
Infected wild animals & 4 & 10 \\
& 3 & 18 \\
Virus smuggling & 2 & 3 \\
& 2 & 1 \\
\hline
\end{tabular}

Number of key informants was 31.

$\dagger$, Numbers of key informants suggesting the $\ddagger$, qualitative measure.

Score shows perceived degree of importance of Rift Valley fever entry risk pathway: $4=$ most important, 3 = important, 2 = less important, 1 = not important.

TABLE 3: Summarised results for qualitative ranking of Rift Valley fever exposure risk pathway in cattle as perceived by the pastoralists' key informants in Ijara, Kenya.

\begin{tabular}{lll}
\hline Exposure risk pathway & Ranking* & $N \dagger$ \\
\hline Infected mosquitoes & 3 & 30 \\
around watering points & 2 & 1 \\
Infected mosquitoes & 3 & 30 \\
in the bomas & 2 & 1 \\
Infected mosquitoes & 3 & 15 \\
in bushy areas & 2 & 16 \\
Infected mosquitoes & 3 & 29 \\
in contact with cattle & 2 & 2 \\
Contamination of & 3 & 1 \\
environment by infected & 2 & 16 \\
materials & 1 & 14 \\
\hline
\end{tabular}

Number of key informants was 31 .

$\dagger$, Numbers of key informants suggesting the $\$$, qualitative measure.

Score shows perceived degree of importance of Rift Valley fever exposure risk pathway: 3 = high, 2 = medium, 1 = low. 
and wild animals and environmental contamination from poor disposal of infected carcasses. However, the locals did not consider transmission from contaminated environment important. The close association between cattle and wildlife was not perceived to be amongst the pathways of RVF transmission in the study area. The areas of contact with wildlife were bushy grazing areas and watering points.

It is important to note that RVFV is endemic in Ijara district. As a result, the likelihood of its entry into Ijara may not be applicable since it is already present. This explains why the communities' perception about the source and/or spread of RVF is the same, namely the role played by mosquitoes.

\section{Recommendations}

Although an RVF decision support tool has been developed for the Horn of Africa (International Livestock Research Institute [ILRI]/Food and Agriculture Organization of the United Nations [FAO] 2009), it seems it is not actually implemented in Ijara. Furthermore, management of cattle and wildlife carcasses would cause a big loss to the pastoralists in Ijara in cases of RVF outbreak given their current perception of their being a low-risk factor. There is therefore a need to implement the RVF decision support tool, especially education and creation of awareness on proper ways of handling both domestic and wild animal carcasses to mitigate or prevent the possibility of RVFV transmission. Awareness should also include the likelihood of RVFV transmission between domestic and wild animals by limiting

TABLE 4: Summarised results for qualitative ranking of Rift Valley fever outbreak consequences in cattle as perceived by the pastoralists' key informants in Ijara, Kenya.

\begin{tabular}{lll}
\hline Consequence risk pathway & Ranking: & $\boldsymbol{N} \dagger$ \\
\hline Morbidity & 4 & 30 \\
Abortion & 3 & 1 \\
& 4 & 10 \\
Mortality & 3 & 20 \\
& 1 & 1 \\
Loss of appetite & 4 & 23 \\
& 3 & 5 \\
Reduced production & 2 & 3 \\
& 4 & 14 \\
Quarantine & 3 & 17 \\
Vaccination & 3 & 13 \\
& 4 & 18 \\
Ban on trade & 4 & 31 \\
\hline
\end{tabular}

Number of key informants was 31.

$\dagger$, Numbers of key informants suggesting the $\ddagger$, qualitative measure.

Score shows perceived degree of importance of Rift Valley fever consequences: $4=$ high, 3
S = medium, 2 = low and 1 = negligible.

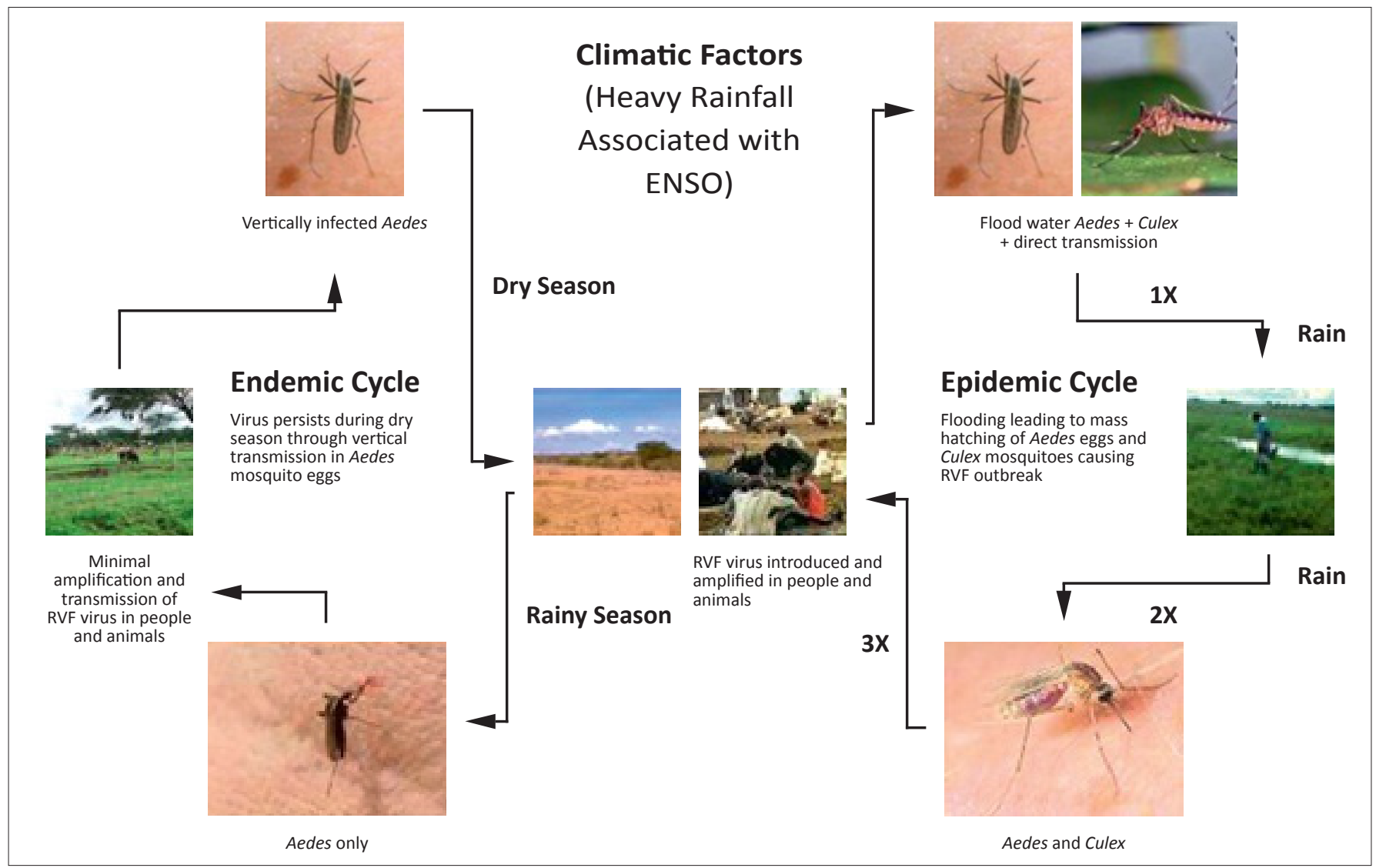

Source: Adapted from Anyamba, A., Linthicum, J.K., Small, J., Britch, S.C., Pak, E., De La Rocque, S. et al., 2010, 'Prediction, assessment of the Rift Valley fever activity in East and Southern Africa 2006-2008 and possible vector control strategies', American Journal of Tropical Medicine and Hygiene 83(Suppl. 2), 43-51. http://dx.doi.org/10.4269/ajtmh.2010.09-0289

The epidemic cycle is precipitated by excessive heavy rainfall associated with the El Niño/Southern Oscillation (ENSO) climatic phenomena. The three Xs depicted in the epidemic cycle represent critical pathways, which can be interrupted by targeted and specific mosquito control activities.

ENSO, El Niño/Southern Oscillation; RVF, Rift Valley fever.

FIGURE 3: Endemic (on left) and epidemic (on right) life cycles of Rift Valley fever involving close association between heavy rainfall conditions, vector Aedes and Culex mosquitoes, domestic animals and humans. 
TABLE 5: A summary discussion table of risk pathway analysis for Rift Valley fever in cattle in ljara, Kenya.

\begin{tabular}{|c|c|c|c|}
\hline Risk pathway & Factors for risk estimation consideration & Risk reduction measure & Risk level according to respondents \\
\hline \multirow[t]{5}{*}{ Infected mosquitoes in cattle grazing areas } & Mosquito abundance & Quarantine & \multirow[t]{5}{*}{ High } \\
\hline & Livestock abundance & Use of mosquito repellents & \\
\hline & Livestock movement patterns & Optimum cattle stocking & \\
\hline & Occurrence of RVF & Draining water in dambos & \\
\hline & RVF risk factors & Clearing bushy vegetation & \\
\hline \multirow{5}{*}{$\begin{array}{l}\text { Infected mosquitoes in bushy areas in } \\
\text { contact with cattle }\end{array}$} & Mosquito abundance & Avoid grazing in bushy areas & \multirow[t]{5}{*}{ High } \\
\hline & Vegetation type and cover & Use of mosquitoes repellents & \\
\hline & Livestock abundance & Appropriate livestock stocking rates & \\
\hline & Occurrence of RVF & - & \\
\hline & Livestock movement patterns & - & \\
\hline \multirow{3}{*}{$\begin{array}{l}\text { Infected mosquitoes in water points where } \\
\text { cattle drink water }\end{array}$} & Mosquito abundance at watering points & Use of mosquito repellents at watering points & \multirow[t]{3}{*}{ High } \\
\hline & $\begin{array}{l}\text { Abundance and distribution of } \\
\text { watering points }\end{array}$ & Optimum number of cattle at watering points & \\
\hline & $\begin{array}{l}\text { Cattle abundance and distribution at } \\
\text { watering points }\end{array}$ & - & \\
\hline \multirow[t]{4}{*}{ Infected mosquitoes in cattle bomas } & Mosquito abundance at cattle bomas & Use of mosquito repellents & \\
\hline & Cattle density at bomas & Proper stocking of livestock & \\
\hline & Cattle movement patterns & Quarantine & \\
\hline & Permanency of cattle bomas & $\begin{array}{l}\text { Lighting fire at cattle bomas to drive } \\
\text { away mosquitoes }\end{array}$ & \\
\hline \multirow{6}{*}{$\begin{array}{l}\text { Infected domestic animals in contact } \\
\text { with mosquitoes }\end{array}$} & Occurrence of RVF in cattle & Quarantine & \multirow[t]{6}{*}{ Medium } \\
\hline & Mosquito abundance & Use of mosquito repellents & \\
\hline & Cattle movement pattern & Surveillance and control of RVF & \\
\hline & - & $\begin{array}{l}\text { Awareness creation and reporting of } \\
\text { sick animals }\end{array}$ & \\
\hline & - & Isolation of sick animals & \\
\hline & - & Ring vaccination & \\
\hline \multirow[t]{3}{*}{ Environmental contamination } & $\begin{array}{l}\text { Abortion rates in domestic and } \\
\text { wild animals }\end{array}$ & $\begin{array}{l}\text { Proper disposal of carcasses by burning } \\
\text { and burying }\end{array}$ & \multirow[t]{3}{*}{ Low } \\
\hline & Disposal of carcasses & $\begin{array}{l}\text { Reducing or avoiding contact between } \\
\text { cattle and wildlife }\end{array}$ & \\
\hline & Wildlife abundance and distribution & $\begin{array}{l}\text { Awareness creation on RVF prevention } \\
\text { and control }\end{array}$ & \\
\hline \multirow[t]{4}{*}{ Infected wildlife in contact with cattle } & Abundance and distribution of wildlife & $\begin{array}{l}\text { Reducing or avoiding contact between } \\
\text { wildlife and cattle }\end{array}$ & \multirow[t]{4}{*}{ High } \\
\hline & Abundance and distribution of cattle & Quarantine & \\
\hline & Cattle movement patterns & $\begin{array}{l}\text { Awareness creation on the risks of cattle coming } \\
\text { into contact with wildlife }\end{array}$ & \\
\hline & Occurrence of RVF in wildlife and cattle & - & \\
\hline \multirow[t]{3}{*}{ Smuggling of virus across the border } & Border control measures & $\begin{array}{l}\text { Screening of cattle and people at } \\
\text { border points }\end{array}$ & \multirow[t]{3}{*}{ Negligible } \\
\hline & Likelihood of terrorist attacks & Security measures against terrorist attacks & \\
\hline & $\begin{array}{l}\text { Movement of cattle and people } \\
\text { across border }\end{array}$ & $\begin{array}{l}\text { Awareness creation, surveillance and } \\
\text { prevention measures }\end{array}$ & \\
\hline \multirow[t]{5}{*}{ Livestock markets } & Likelihood of trade of infected cattle & $\begin{array}{l}\text { Screening of livestock before being allowed } \\
\text { to move to the market centres }\end{array}$ & \multirow[t]{5}{*}{ Low } \\
\hline & Trade routes & $\begin{array}{l}\text { Formulation and implementation of cattle } \\
\text { movement regulations }\end{array}$ & \\
\hline & $\begin{array}{l}\text { Implementation of movement } \\
\text { of livestock regulations }\end{array}$ & $\begin{array}{l}\text { Awareness creation on risks of trading } \\
\text { in infected cattle }\end{array}$ & \\
\hline & - & Ban of cattle trade during outbreaks & \\
\hline & - & Quarantine & \\
\hline
\end{tabular}

RVF, Rift Valley fever.

wild-domestic animal interaction to a minimum. On the other hand, strategic vaccination, if carried out, can help protect the animals and reduce losses in case of an outbreak.

Continuous surveillance of RVF in Ijara in domestic animals, wildlife, humans and vectors as well as environmental monitoring of rainfall pattern should be carried out together with all the stakeholders to provide early warning signs that can help in preparedness, control and prevention of the occurrence of RVF.

\section{Acknowledgements}

We wish to express our thanks to the International Development Research Centre (IDRC) for financial support that facilitated this research. We also appreciate the overwhelming support and assistance from members of the IDRC RVF ecohealth project management committee. We recognise the invaluable support from the field key informant interview facilitators (James Wauna [International Centre for Insect Physiology and Ecology \{ICIPE $\}]$, Denis Njeru 
Gitonga [District Livestock Production Officer, Ijara], Omar Chatsi [Deputy District Veterinary Officer, Ijara]), the herd owners, herdsmen, Kenya Wildlife Service (KWS) personnel and local leaders who offered overwhelming support during interviews. Lastly, we recognise the administrative support from the ICIPE.

\section{Competing interests}

The authors declare that they have no financial or personal relationship(s) that may have inappropriately influenced them in writing this article.

\section{Authors' contributions}

The study forms part of a bigger project funded by the IDRC, implemented by the ICIPE's lead agency and two implementing partners, the State Department of Veterinary Services of the government of Kenya and the University of Nairobi. R.S. (ICIPE), H.A. (ICIPE), M.M. (Ministry of Agriculture, Livestock and Fisheries), J.K. (Ministry of Agriculture, Livestock and Fisheries), W.O-O. (University of Nairobi) were the project initiators and guided the holistic project design and implementation. T.T.O.L. (ICIPE) was engaged in the design of the study, producing and helping in the interpretation of GIS maps. N.O.O. (University of Nairobi) carried out the study, led the design, actual fieldwork, analysis and presentation of the findings under the supervision of W.O.O. (University of Nairobi), M.M., S.O. (Emergency Centre for Transboundary Animal Diseases) and P.B.G. (University of Nairobi), who guided and supervised every stage of the study.

\section{References}

Al-Afaleg A.I., Abu Elzein, E.M., Mousa, S.M. \& Abbas, A.M., 2003, 'A retrospective study on Rift Valley fever in Saudi Arabia', Revue scientifique et technique, Office international des Epizooties 22, 867-871.
Anyangu, A.S., Gould, L.H., Sharif, S.K., Nguku, P.M., Omolo, J.O., Mutonga, D. et al., 2010, 'Risk factors for severe Rift Valley fever infection in Kenya, 2007', American Journal of Tropical Medicine and Hygiene 83(Suppl. 2), 14-21. http://dx.doi. org/10.4269/ajtmh.2010.09-0293

Anyamba, A., Linthicum, J.K., Small, J., Britch, S.C., Pak, E., De La Rocque, S. et al., 2010, 'Prediction, assessment of the Rift Valley fever activity in East and Southern Africa 2006-2008 and possible vector control strategies', American Journal of Tropical Medicine and Hygiene 83(Suppl. 2), 43-51. http://dx.doi.org/10.4269/ ajtmh.2010.09-0289

Breiman, F.R., Minjauw, B., Sharif, S.K., Ithondeka, P. \& Njenga, M.K., 2010, 'Rift Valley fever: Scientific pathways toward public health prevention and response' American Journal of Tropical Medicine and Hygiene 83(Suppl. 2), 1-4. http:// dx.doi.org/10.4269/ajtmh.2010.83s2a01

Centers for Disease Control and Prevention (CDC), 2007, 'Rift Valley fever outbreak - Kenya, November 2006-January 2007', Morbidity and Mortality Weekly Report 56, 73-76.

Chambers, R., 1981, 'Rapid rural appraisal: Rationale and repertoire', IDS discussion paper no. 155, Institute for Development Studies, Sussex.

Chambers, R., 1994, 'Participatory rural appraisal: Analysis of experience', World Development 22(9), 1253. http://dx.doi.org/10.1016/0305-750X(94)90003-5

Davies, F.G., Linthicum, K.J. \& James, A.D., 1985, 'Rainfall and epizootic Rift Valley fever', Bulletin of the World Health Organization 63, 941-943.

Evans, A., Gakuya, J.T., Paweska, M., Rostal, L., Akoolo, L., Van Vuren, P.J. et al., 2008 'Prevalence of antibodies against Rift Valley Fever in Kenyan wildlife', Epidemiology and Infection 136, 1261-1269. http://dx.doi.org/10.1017/S0950268807009806

Gerdes, G.H., 2004, 'Rift Valley fever', Revue scientifique et technique, Office international des Épizooties 23, 613-623.

International Livestock Research Institute (ILRI)/ Food and Agriculture Organization of the United Nations (FAO), 2009, Decision-support tool for prevention and control of Rift Valley fever epizootics in the Greater Horn of Africa, Version 1, ILRI Manual and Guides No. 7, International Livestock Research Institute, Nairobi and Food and Agriculture Organization of the United Nations, Rome.

Kasari, T.R., Carr, D.A., Lynn, T.V. \& Weaver, J.T., 2008, 'Evaluation of pathways for release of Rift Valley fever virus into domestic ruminant livestock, ruminant wildlife, and human populations in the continental United States', Journal of the American Veterinary Medical Association 232(4), 514-529. http://dx.doi. org/10.2460/javma.232.4.514

Murithi, R.M., Munyua, P., Ithondeka, P.M., Macharia, J.M., Hightower, A., Luman, E.T. et al., 2010, 'Rift Valley fever in Kenya: History of epizootics and identification of vulnerable districts', Epidemiology and Infection 139(3), 372-380. http://dx.doi. vulnerable districts', Epidemiology
org/10.1017/S0950268810001020

Nguku, M.P., Sharif, S.K., Mutonga, D., Amwayi, S., Omolo, J., Mohammed, O. et al., 2010, 'An investigation of a major outbreak in Kenya: 2006-2007', American Journal of Tropical Medicine and Hygiene 83(Suppl. 2), 5-13. http://dx.doi. org/10.4269/ajtmh.2010.09-0288

Peters, C.J. \& Linthicum, K.J., 1994, 'Rift Valley fever', in G.W. Beran (ed.), Handbook of Zoonoses, 2nd edn., Section B: Viral Zoonoses, pp. 125-138, CRC Press, Boca Raton.

World Bank, 2004, 'Monitoring and evaluations: Some tools, methods and approaches', viewed 20 August 2014, from http://www.worldbank.org/ieg/ecd/tools/

Woods, C.W. \& Karpati, A.M., 2002, 'An outbreak of Rift Valley fever in north eastern Kenya, 1997-1998', Emerging Infectious Diseases 8, 138-144. http://dx.doi. org/10.3201/eid0802.010023 